\title{
STRUCTURAL EVOLUTION OF THE KILOMBERO RIFT BASIN IN CENTRAL TANZANIA
}

\author{
AH Mruma \\ Department of Geology, University of Dar es Salaam \\ P.O. Box 35052, Dar es Salaam, Tanzania
}

\begin{abstract}
Detailed geological and structural investigations at the northwestern scarp of the Cenozoic Kilombero Rift allow the drawing of its structural evolution and establishment of stress conditions that prevailed at the different deformational episodes at this rift zone. The structure, where the northwestern scarp of the Cenozoic Kilombero Rift System is located, starts by ductile deformation of granitic and gabbroic rock masses leading to the formation of gneissic fabric and b-mineral lineation in the rocks. This deformation is of Precambrian age (most probably a Pan African deformation) and its kinematics are characterized by $320^{\circ} / 20^{\circ}$ tectonic transport direction $\left(\lambda_{1}\right)$. Later the area was subjected to at least two brittle deformations (faults and joints) of Permo - Triasic and Cenozoic ages. These brittle deformations developed $E-W$ trending (SET-1) and NE-SW trending (SET-2) conjugate discontinuities (joints and faults). All of them have very high dip angles (about $80^{\circ}$ ) and they dip to the south and southeast, respectively. Their configurations imply kinematics with NNW-SSE trending sub-horizontal $\lambda_{1}$, sub-vertical $\lambda_{2}$, and ENE-WSW trending sub-horizontal $\lambda_{3}$. This trend suggests that the stress regime that accounts for their formation had ENE trending sub-horizontal $\sigma_{l}$ maximum compressive stress, subvertical $\sigma_{2}$ intermediate compressive stress and a NNW trending sub-horizontal $\sigma_{3}$ minimum compressive stress.
\end{abstract}

Most of these discontinuities show reverse sense of displacement different form the main Kilombero fault (which has a normal throw) though both of them have the same trend. One could argue that the discontinuities with reverse 
displacement pre-dates the main Cenozoic Kilombero rift, the later being formed by reactivation of the earlier. The discontinuities with reverse displacement could be of PermoTriasic age associated with Karoo tectonics. It is also possible that the reverse discontinuities and the Kilombero rift are coeval but the reverse sense of displacement in the earlier is induced by large-scale block rotation. In this case, both the reverse discontinuities and the Kilombero rift could be of Permo-Triasic age but reactivated during the Cenozoic period particularly along the main Kilombero Rift. However, both the reverse discontinuities and the Kilombero rift could also be of Cenozoic age and that the imprints of PermoTriasic tectonics are missing in the study area. The PermoTriasic deformation imprints could be developed further to the southeast of the area where they are now concealed by the Cenozoic cover in the Kilombero plain. Dating of these discontinuities is therefore recommended in order to distinguish those of Permo-Triasic and Cenozoic ages.

\section{INTRODUCTION}

The well pronounced eastern branch of the East African Rift System that stretches southwards as a well defined rift valley from Ethiopia through Kenya and northern Tanzania branches into ill-defined arms as it crosses the Tanzanian Archaean Craton (Fig 1). One of these ill-defined branches is the NE-trending Kilombero Rift located in central Tanzania (Fig 2). The Kilombero Rift System is a northeasterly continuation of the Ruhuhu Rift Basin and further to the north the Kidodi-Mkata Rift Basin joins the Kilombero Rift. Both the Ruhuhu and Kidodi basins are known to be underlain by Permo-Triasic Karoo sediments (Dypvik et al. 1997, Kaaya 1992, Kreuser 1983, Nielsen et al. 1996, Wopfner \& Kaaya 1992). Recent studies have shown that some parts of the East African Rift System cuts and/or reactivates known Precambrian shear zones, Permo-Triassic, Cretaceous or Paleogene rift basins. However the spatial extent of these earlier structural systems are poorly known (Hendrie et al. 1994, Ebinger \& Ibrahim 1994, Theunissen et al. 1997, Nielsen et al. 1999). 


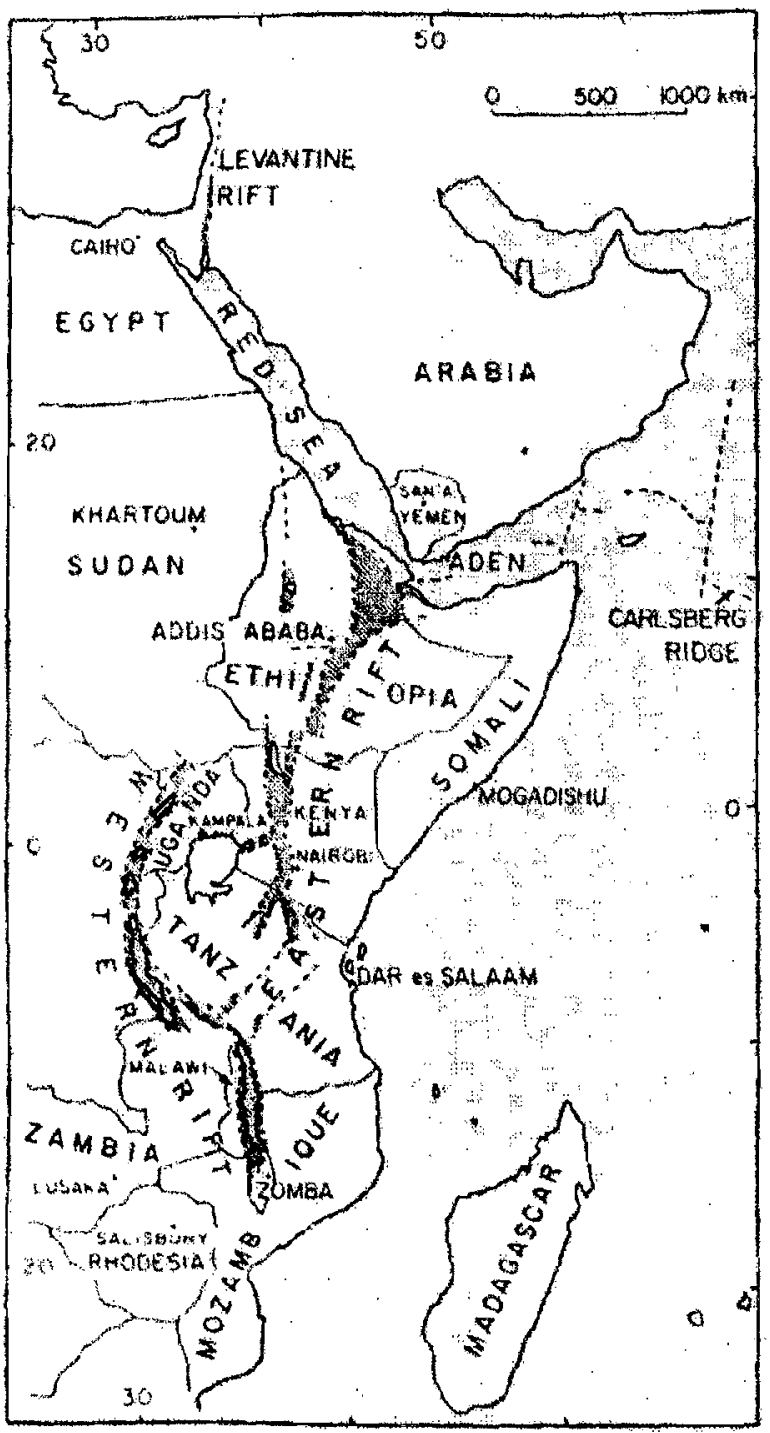

Fig. 1: Geographical distribution of the East African Rift System

\section{METHODS}

The present study assessed the structural evolution of the Kilombero Rift and it proposes the stress conditions that prevailed at the different deformational episodes of the area. The study also examined the way by which earlier 


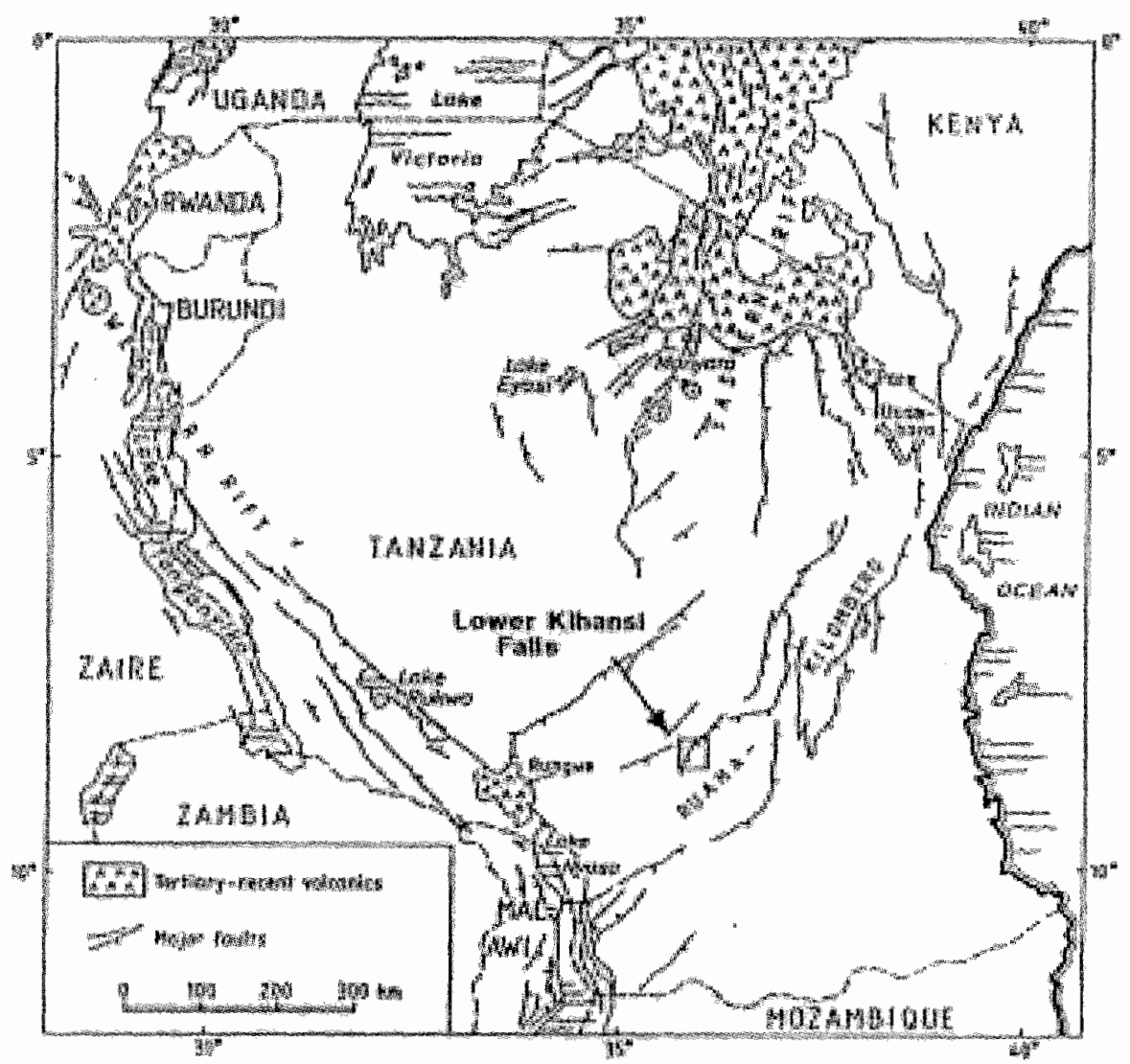

Fig. 2: Geological setting of the northwest flanks of the Kilombero Rift in Tanzania

structures of the area, starting from the Precambrian ones, could have controlled the geometry of later structures. The assessment is based on detailed geological and structural mapping in the northwestern boundary of the Kilombero Rift System around Kihansi and Mlimba (Fig 2). Identification and characterization of geological structures and deduction of palaeo-stresses that accounts for the formation of the structures were obtained through detailed structural studies.

\section{RESULTS}

\section{Regional geology}

The NE-trending Kilombero Rift cuts the biotite and quartzo-feldspathic gneisses of the Precambrian (Pan-African) Mozambique Belt, obliquely to the regional trend. The section of the Kilombero Rift zone studied is located at the Udzungwa Scarp (Fig. 2), that marks the NW fault scarp of the 
Kilombero Rift forming the southeastern boundary of the Udzungwa Ranges rising 1,100 to $2,000 \mathrm{~m}$ above sea level. The Udzungwa Scarp is formed by large-scale block faulting and tilting of the Kilombero Rift System. The flatlying alluvial marshlands of the Kilombero valley with an elevation of approximately 280 to $300 \mathrm{~m}$ above sea level (to the south of the fault scarp) are the down-thrown block of the rifting. The Udzungwa Ranges (northwest of the fault scarp), that area composed of the Pan-African gneisses, form the uplifted block.

\section{Geology of the lithotypes}

\section{Biotite gneiss}

The dominant lithology at the study area is foliated, grayish biotite gneiss with thin (few cm thick) concordant dark colored, biotite-rich and light colored quartzo-feldspathic gneissic bands. All the bands contain prominent mineral foliation parallel to the gneissic fabric. The dominant minerals of the rock are biotite, microcline, plagioclase and quartz. Its accessory minerals include epidote, sphene, apatite, muscovite, chlorite and apatite.

In several places, the quartzo-feldspathic bands, composed of microcline, plagioclase and quartz, occur as ptygmatic veins in the biotite gneiss crosscutting the foliation imparting migmatitic structure to the gneiss. In some localized areas the biotite gneiss occurs as zones of intense deformation within an undeformed massive, unfoliated, very coarse granodiorite-granite with randomly crosscutting aplite dykes. The granodiorite also contain several mafic (gabbroic) enclaves. The dominant minerals in the granodiorite-granite are microcline, plagioclase, quartz and few hornblende, whereas the aplite dykes contain microcline, plagioclase, quartz and very few flakes of biotite and muscovite.

A transitional phenomenon from undeformed granodiorite-granite to partly foliated migmatitic gneiss to highly foliated biotite gneiss is observed in places suggesting that the granodiorite-granite is the parent rock of the biotite gneiss, the latter being formed by intense deformation and metamorphism. The quartzo-feldspathic gneiss described below could be a result of the deformation of the aplite dykes. 


\section{Quartzo-feldspathic gneiss}

Frequently the biotite gneiss contains intercalations of up to $1 \mathrm{~m}$ thick and several tens of meters long discontinuous bands of foliated white to pinkish quartzo-feldspathic gneiss. The mineral foliation in these quartzofeldspathic gneissic bands is parallel to the elongation direction of the bands. The quartzo-felspathic bands themselves are, to a large extent, concordant to the gneissic and mineral foliations in the biotite gneiss except in the migmatitic zones where they cross-cut the foliation.

\section{Amphibole biotite schist}

Occasionally the biotite gnesiss is concordantly interbanded with dark colored, very strongly schistose amphibole biotite schist. This lithotype is usually very thin $(1 / 2 \mathrm{~m}$ to few $\mathrm{cm}$ thick) except in few places where it occurs with up to $5 \mathrm{~m}$ thick units in the biotite gneiss. This rock unit does not extend laterally for large lengths. Maximum lateral extension is about 20 $\mathrm{m}$. Dominant minerals in this lithology are biotite, plagioclase, quartz, hornblende, chlorite and epidote.

At those places where the units are rather thick, the amphibolitic biotite schist wrap around boudins of very corse homogeneous dioritic-gabbroic rocks that seem to have escaped the deformation, suggesting that the parent lithology of the schist has massive diorite-gabbro magmatic kindred that are probably coeval with the granodiorite-granite.

\section{Dolerite}

Few outcrop of a N-S trending dolerite dyke are found in the study area cutting the biotite gneiss.

\section{Structures}

\section{Primary structures}

The primary (pre-deformational) rocks of the study area i.e. the granodiorite-granite and the diorite-gabbro are very coarse, homogeneous, unfoliated and they are cut by randomly oriented, fine-grained, homogeneous aplite dykes. 


\section{Secondary (deformational) structures}

\section{(a) Ductile structures}

The granodiorite-granite and diorite-gabbro rocks appear to have been subjected to regional deformation (and metamorphism at lower amphibolite facies conditions) that imparted pervasive ductile gneissic fabric, mineral foliation, mineral lineation and folds. This deformation caused large-scale transposition of rocks and locally it is associated with migmatization.

The gneissic layering (compositional banding) is mostly developed in the biotite gneiss and in the gneissose amphibolitic biotite schist. This layering is poorly developed in the migmatitic portions and it is absent in the relic granodiorite-granite and diorite-gabbro parent rock masses that escaped the deformation. Thin alternating white colored quartzo-feldspathic and dark colored ferromagnesian rich layers define the gneissic layerings. They normally form concordant layers in most outcrops (except in migmatitic portions) but frequently they also occur as low-angle cross cutting layers (i.e. anastormosing bands) confirming a high level of transposition during their formation. The gneissic layering has a general strike of 020 and dip about $35^{\circ}$ towards WNW but occasionally they show varying attitudes due to folding and migmatization (Fig. 3).

The biotite gneiss, quartzo-felspathic gneiss and the amphibolitic biotite schist contain pervasive mineral foliation defined by preferred orientation of biotite, hornblende, chlorite, muscovite and flattened quartz. The mineral foliation is poorly developed in the migmatitic portions of the rocks and even more crude or totally missing in the relic granodiorite-granite and diorite-gabbro rock masses. In the amphibolitic biotite schist seams the mineral foliation defined by oriented coarse biotite flakes is so pervasive that the unit is very fissile and can easily split along the planes of schistosity.

Mineral lineation defined by preferred orientation of elongated minerals (e.g. elongated quartz and hornblende) is present in all the gneisses. It is a blineation with a general plunge of $20^{\circ}$ towards $320^{\circ}$. This direction of mineral lineation is therefore taken to be the $\lambda_{1-}$ shear direction of the Precambrian straining that accounts for the formation of the gneissic fabric.

Isoclinal to tight folds deforming the gneissic layering are common but, in general, their limb zones are highly attenuated and transposed; that is why the poles of the gneissic layering plot on a single maxima (Fig 3) and not 
along a girdle. The fold axes are generally plunging $20^{\circ}$ towards $300^{\circ}-320^{\circ}$, i.e. parallel to the mineral foliation suggesting that they are sheath folds.



Equal area projection, lower hemisphere

Fig. 3: Stereographic projection for gneissic fabric of the northwestern flank of the Kilombero Rift, Tanzania

(b) Brittle structures

The study area appear to have been affected by faulting that led to the formation of the Udzungwa Scarp. The actual fault planes are rarely seen on the normal rock outcrops exposed along the slopes of the Udzungwa Scarp.

Most of the faults were first inferred from the interpretation of SPOT images, aerial photographs. However, detailed mapping and geomorphological studies have confirmed most of the initially inferred faults. Some of these faults are trending WNW-ESE to E-W. These are herein referred as FAULT-SET 1. The study area is also dominated by another set of faults (referred herein as FAULT-SET 2) that had a general trend of NESW. Some very few NW-SE trending faults (referred herein as FAULT-SET 3 ) that swing to almost N-S are also present. All these fault sets are subvertical with dip angle greater than 70 . The senses of displacements, slicken sides and infills in these discontinuities are here under described in detail. 
Rocks of the whole study area are jointed but the intensity of jointing varies from place to place. In general, the intensity of jointing and fracturing was high at places where there are distinct faults. However, there are also several highly jointed sites with no faults. Disregarding the intensely fractured zones close to the faults, in general the intensity of fracturing in the area decreases northwards as one moves away from the Kilombero fault into the Udzungwa ranges. Areas close to the foot of the Udzungwa Scarp are somehow intensely fractured whereas those at Udzungwa plateau are relatively less fractured.

All the joints in the study area are steeply dipping (dip angle varying from $70^{\circ}$ to $90^{\circ}$ - average dip angle $=80^{\circ}-85^{\circ}$ ). They occur in conjugate form with two sets. Set-lhas a general E-W strike and it dips to the south but occasionally to the north also. Set- 2 has a general NE-SW strike and it dips to the SE but occasionally to the NW also. The general attitudes of these joints are presented in the stereogram (Fig. 4).

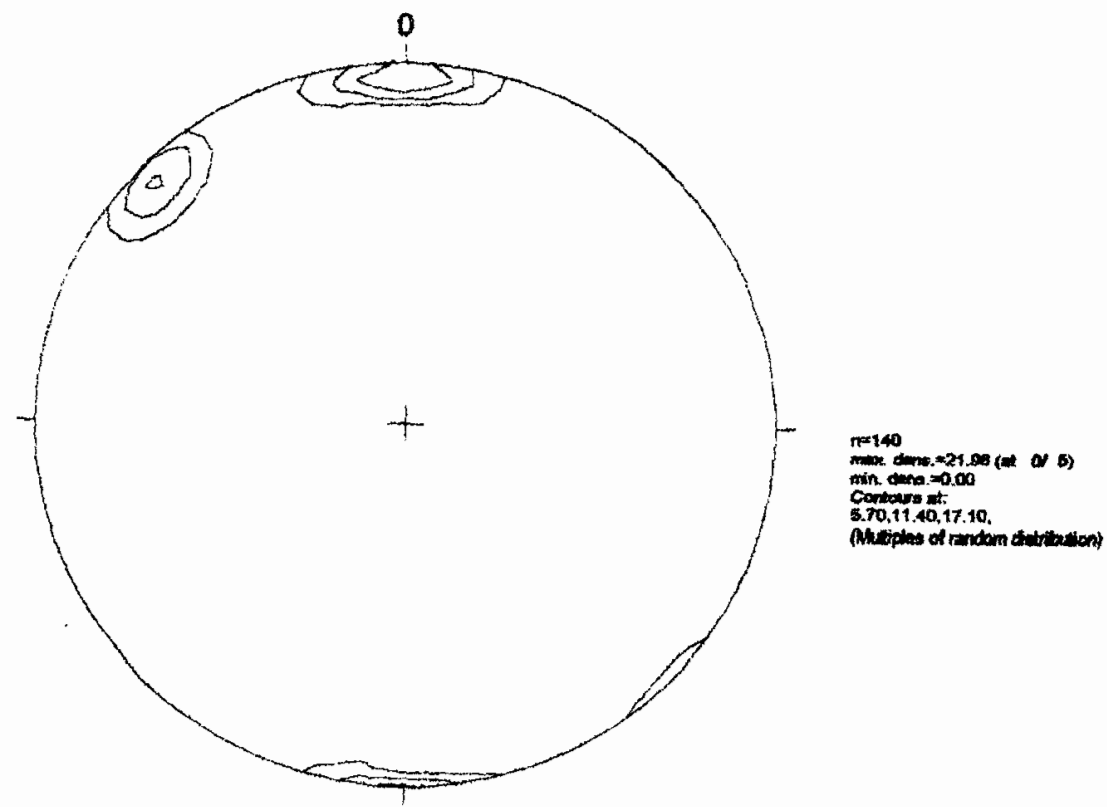

Equal area projection, lower hemisphere

Fig. 4: Stereographic projection for joints of the northwestern flank of the Kilombero Rift, Tanzania 
In the field, the intensities of these sets of joints are never the same within a given area. There are zones dominated by set-1 joints (set- 2 being less developed) whereas in other zones the domination is vice verse. Most of the fractures do not show significant amount of displacement. However, a good number of them show displacement and it is rather surprising to note that most of them (even those which strike E-W and dip to the south) show reverse sense of block-movement. This sense of displacement does not match with the geomorphology of the southerly sloping Udzungwa Scarp with its southern block (the Kilombero valley) being down-throwned relative to its northern block (the Udzungwa Ranges). However, there are few discontinuities with normal displacement. Frequently displacements are also noted along some reactivated foliation planes in the gneisses. These reactivated foliation planes are restricted along the schistose micaseous seams.

Some of these joints are filled with very fine reddish clay possibly originating from weathering but numerous joints without in-fills are also seen all over the area. Except for the difference in their strike-trends, the two conjugate discontinuity-sets are similar in many aspects such as the magnitude of opening, sense and magnitude of displacements, in-fills and lack of slicken sides. There is also no evidence of one set cutting and displacing the other. This situation leads to an assumption that most of these discontinuities are coeval.

There is no confirming evidence that the brecciar zones were formed by tectonic grinding and milling. Most of the breccias appear to have been formed by closely spaced joints without any significant rolling of the brecciar pieces. These sub-vertical discontinuities are surprisingly lacking slicken sides. Slicken sides are restricted along the gently dipping reactivated micaseous seams and they are mostly dip-slip lineations.

\section{DISCUSSION}

The sets of joints are geometrically similar to the set- 1 and set- 2 fault systems described above. Also, with the exception of those few zones of reactivations of the mica seams, the trend of joints and faults are not related to the trend of the Precambrian gneissic fabrics. This situation is different from that at the western arm of the East African Rift System where much of its trend is controlled by the Precambrian mylonitic fabric in the Ubendian Belt (Theunissen et al. 1997). 
The lack of slicken sides and tectonically crushed and rotated breccias suggest that the sub-vertical joints were mostly formed under extensional tectonic regime without much compressional stress. Such crustal tensional stresses are normally a result of crustal updoming causing crustal stretching near the surface. Faired and Reeves (1977) have already revealed that the rift zones of Africa correspond to zones of lithospheric thinning that may be the isostatic response of the crust to upward flow of a low density upper mantle (asthenosphere). This updoming is causing crustal stretching (extension) that may eventually lead to the break up of the upper crust (i.e. jointing and faulting). The geometrical relationship of the two sets of the conjugate joints and those of the conjugate faults suggests that the tectonic regime that accounts for the development of these discontinuities had NNWSSE oriented sub-horizontal tensional stresses $\left(\sigma_{3}\right)$ producing NNW-SSE sub-horizontal extensional strains $\left(\lambda_{1}\right)$ (Fig. 5).

The sense of displacement of most for these discontinuities (reverse sense) did not match with that of the general geomorphology of the Udzungwa Scarp (the northwestern Kilombero Rift) suggesting a situation where the discontinuities and the scarp were formed by different episodes of block movements with or without large time gap between them. It is important to note that Kilombero Rift is a northeasterly continuation of the Ruhuhu Basin that is underlain by Karoo sediments. In addition, further to the northeast, the Kilombero Rift is joined to the Kidodi-Mkata fault-controlled basin that also contains sediments of Karroo age. Therefore it is very possible that the discontinuities with reverse sense of displacement are of Karoo age. It is most likely that the normal faults of the Udzungwa Scarp were formed much later (at Cenozoic period) through reactivation of the preexisting discontinuities that had reverse sense of displacement. It is also possible that both the main Kilombero Fault (Udzungwa scarp) and the SE dipping discontinuities with reverse sense of displacement are coeval but the reverse nature of the displacement in the discontinuities is due to large-scale block rotation and tilting in the cause of faulting (Fig 6). 


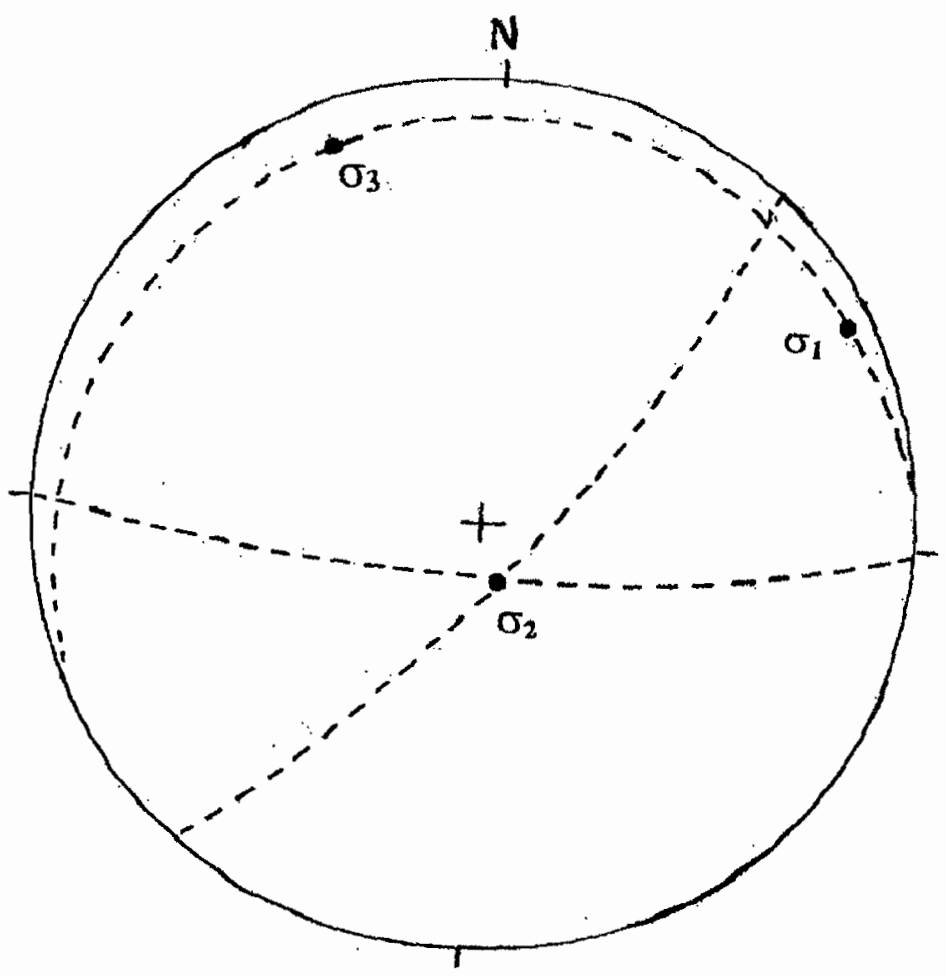

Fig. 5: Orientation of axes of stress that suggests for the formation of the conjugate joints in the northwestern flank of the Kilombero Rift, Tanzania

Both the discontinuities with reverse displacement and the Kilombero Rift could be of Karoo age but reactivated during the Cenozoic period particularly along the main Kilombero Rift. However, both the discontinuities and the Kilombero Rift could also be Cenozoic, imprints of Karoo deformation are totally missing in the study area. The Karoo faults could be located further to the southeast in the areas concealed by the Cenozoic cover in the Kilombero plain. 

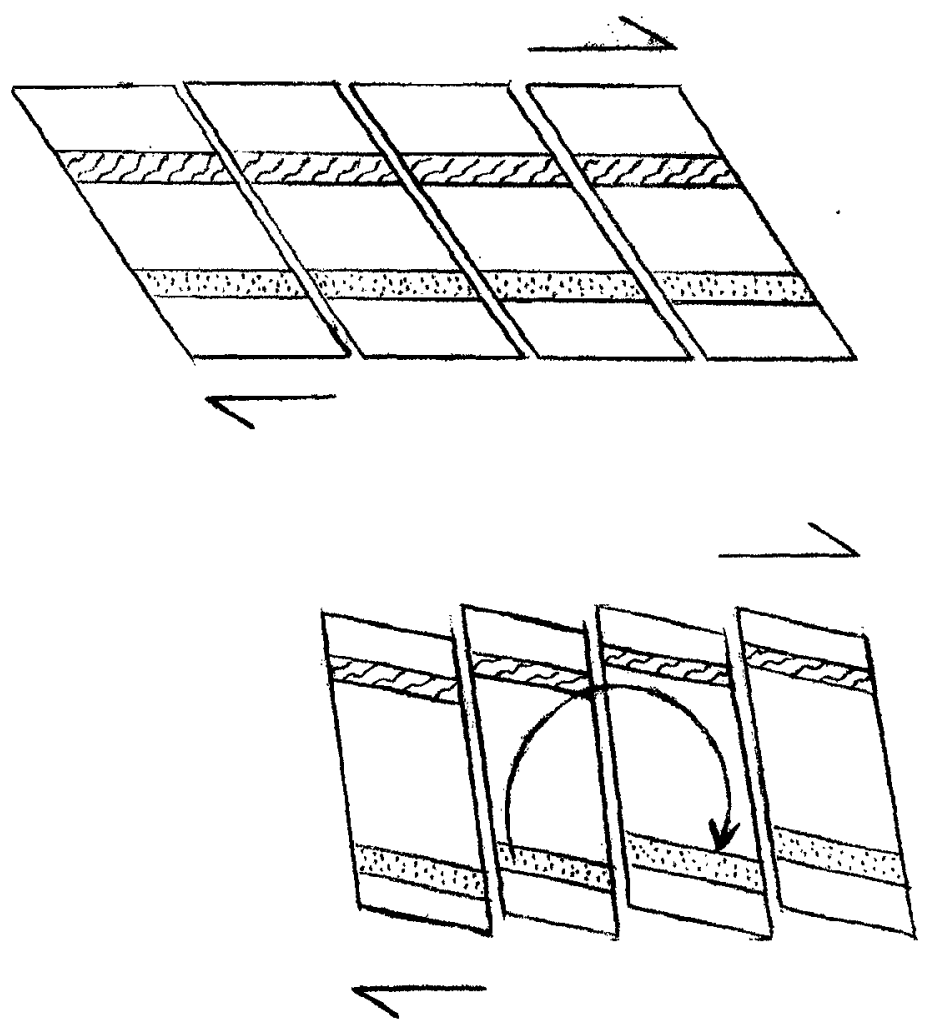

Fig. 6: Domino (booskelf) rotation that may account for the apparent reverse sense of displacement observed in the northwestern flanks of the Kilombero Rift, Tanzania

It is strongly recommended that systematic dating of the joints and faults be done in the area in order to distinguish between Karoo and Cenozoic discontinuities.

\section{REFERENCES}

Dypvik H, Nielsen O and Kaaya C 1997 The Karoo (Permian) succession of the Kilombero Valley, Tanzania. Geophysical Bulletin 48: 53-56

Ebinger CJ and Ibrahim A 1994 Multiple episodes of rifting in East Africa. Geol. Rundsch 83: 689-702

Hendrie DB, Kusznir NJ, Morley CK and Ebinger CJ 1994 Cenozoic extension in northern Kenya: a quantitative model of rift basin development in the Turkana region, northern Kenya Tectonophysics 236: 409-438

Kaaya CZ 1992 Depositional environment of late Perian Karoo beds in the Ruhuhu Basin and Mikumi area of Tanzania. Geologisches 
Institut der Universitaet Koeln, Sonderveroeffintlichungen 83: $126 \mathrm{p}$.

Kreuser T 1983 Stratigraphie der Karoo-Becken in Ost-Tanzania. Geologisches Institut der Universitaet Koeln, Sonderveroeffintlichungen $45: 217 \mathrm{p}$

Nielsen O, Dypvic H, Kaaya C and Kilembe E 1996 Karoo sediments and structural development of the Kilombero Rift, Tanzania. Proceedings of the $95^{\text {th }}$ International Conference, Geological Society of Africa 1995: 97-124

Nielsen O, Dypvic H, Kaaya C and Kilembe E 1999 Tectono-sedimentary development of the (Permian) Karoo sediments in the Kilombero rift valley, Tanzania. Journal of African Earth Sciences 29: 393-409

Theunissen K, Klerkx J, Melnikov A and Mruma AH 1997 Mechanisms of inheritance of rift faulting in the western branch of the East African Rift, Tanzania. Tectonics 15(4): $776-790$

Wopfner H and Kaaya CZ 1992 Syndepositional Karoo rifting in the Ruhuhu and Selous Basins, Tanzania. UNESCO, Geology for Economic Development, Newsletter 9: 159-168 